\title{
HUBUNGAN MUTU PELAYANAN KESEHATAN DAN KEPUASAN PESERTA BPJS DI POLIKLINIK PENYAKIT DALAM RUMAH SAKIT ABDUL MOELOEK PROVINSI LAMPUNG 2015
}

\author{
Jordy Oktobiannobel ${ }^{1}$, Nita Sahara ${ }^{2}$,Elitha M. Utari ${ }^{3}$
}

1Departemen Farmakologi, Fakultas Kedokteran, Universitas Malahayati
${ }^{2}$ Departemen Imunologi, Fakultas Kedokteran, Universiats Malahayati
${ }^{3}$ Departemen Fisiologi, Fakultas Kedokteran, Universitas Malahayati

Abstract: Relationship between the Quality of Health Services and the Satisfaction of Bpjs Participants in the Internal Medicine Polyclinic at Abdul Moeloek Hospital in Lampung Province 2015. Satisfaction is the level of perceived state of someone who is the result of comparing the products performances that are perceived in relation to someone's expectations. In hospitals, patient satisfaction is very important for the sustainability of the hospital. And that affects the satisfaction is the health service quality. The purpose of this study was to determine the relation of health service quality and BPJS member satisfaction in internal disease polyclinic of dr. H. Abdul Moeloek Hospital Lampung Province in 2015.This type of research is observational analytic with cross sectional approach. Sampling using accidental sampling with sample of 256 people. Data analysis are univariate and bivariate with Chi-square test.Research showed that there is a relation between tangible $=0.000$ $(p<0.05)$, reliability $=0.002(p<0.05)$, responsiveness $=0.000 \quad(p<0.05)$, assurance $=0.000 \quad(p<0.05)$, empathy $=0.000(p<0.05)$ and BPJS member satisfaction in internal disease polyclinic of dr. $\mathrm{H}$. Abdul Moeloek Hospital Lampung Province in 2015.The conclusion from this study is that there's a relations between health service quality and BPJS member satisfaction in internal disease inpatient of dr. Abdul Moeloek Hospital Lampung Province in 2015.

Keyword: BPJS member satisfaction, health service quality

\begin{abstract}
Abstrak: Hubungan Mutu Pelayanan Kesehatan dan Kepuasan Peserta Bpjs Di Poliklinik Penyakit Dalam Rumah Sakit Abdul Moeloek Provinsi Lampung 2015. Kepuasan adalah tingkat keadaan yang dirasakan seseorang yang merupakan hasil dari membandingkan penampilan produk yang dirasakan dalam hubungannya dengan harapan seseorang. Dalam rumah sakit, kepuasan pasien sangat penting untuk keberlangsungan rumah sakit dan yang mempengaruhi kepuasan tersebut yaitu mutu pelayanan rumah sakit yang ada. Tujuan penelitian ini untuk mengetahui hubungan mutu pelayanan kesehatan dan kepuasan peserta BPJS di poliklinik penyakit dalam RS dr. H. Abdul Moeloek Provinsi Lampung. Jenis penelitian ini adalah observasi analitik dengan pendekatan cross sectional. Penarikan sampel menggunakan accidental sampling dengan jumlah sampel 256 orang. Analisis data yang dilakukan adalah univariat dan bivariat dengan uji Chi-square. Hasil Penelitian didapatkan bahwa ada hubungan antara tangible $=0,000(p<0,05)$, reliability $=0,002(p<0,05)$, responsiveness $=0,000(p<0,05)$, assurance $=0,000(p<0,05)$, empathy $=0,000(p<0,05)$ dengan kepuasan peserta BPJS poliklinik penyakit dalam RS dr. H. Abdul Moeloek Provinsi Lampung 2015. Kesimpulan dari penelitian ini adalah ada hubungan antara mutu pelayanan kesehatan dan kepuasan peserta BPJS Poliklinik Penyakit Dalam RS dr. H. Abdul Moeloek Provinsi Lampung 2015.
\end{abstract}

Kata Kunci: kepuasan peserta BPJS, mutu pelayanan kesehatan. 


\section{PENDAHULUAN}

Kepuasan pelanggan (customer satisfaction): "Kepuasan adalah tingkat keadaan yang dirasakan seseorang yang merupakan hasil dari membandingkan penampilan atau outcome produk yang dirasakan dalam hubungannya dengan harapan seseorang" (Wiyono, 1999). Termasuk kepuasan pasien terhadap pelayanan yang diberikan oleh rumah sakit.

Rumah sakit adalah institusi pelayanan kesehatan yang menyelenggarakan pelayanan kesehatan perseorangan secara paripurna yang menyediakan pelayanan rawat inap, rawat jalan, dan gawat darurat (UU RI no. 44, 2009) Sejak awal tahun 1990-an, rumah sakit di Indonesia mengalami perubahan paradigma, di mana rumah sakit tidak sebagai unit sosial, tetapi menjadi unit sosio-ekonomi. Rumah sakit tetap mempunyai tanggung jawab sosial tetapi dalam pengelolaan keuangannya menerapkan prinsipprinsip ekonomi (Depkes RI, 2002) Jumlah rumah sakit di Indonesia, terhitung tanggal 1 Januari, pada tahun 2012 sebanyak 1.719 rumah sakit, pada tahun 2013 sebanyak 2.083 rumah sakit, dan pada tahun 2014 sebanyak 2.228 rumah sakit (Depkes RI) Dengan perkembangan rumah sakit ini, maka timbul persaingan antar rumah sakit di mana sebagai salah satu badan usaha yang mencari keuntungan (profit making) (Azwar, 2010). Sehingga setiap rumah sakit akan berlomba-lomba dalam memberikan pelayanan kepada masyarakat agar rumah sakit tersebut tetap bertahan.

$\mathrm{Hal}$ ini menunjukkan, bahwa kepuasan dari pengguna pelayanan rumah sakit, dalam hal ini adalah pasien, merupakan hal yang penting. Dampak utama dari kepuasan adalah pangsa pasar, dan selanjutnya pada pendapatan dari pelayanan tersebut. Sebaliknya, ketidakpuasan akan menimbulkan adanya keluhan dan tuntutan (Wiyono, 1999) Salah satu hal yang berkaitan dengan kepuasan pasien adalah mutu dari pelayanan rumah sakit itu sendiri.

Mutu pelayanan rumah sakit sangat penting, karena akan mempengaruhi langsung kepuasan dari pasien. Mutu pelayanan kesehatan menunjukkan tingkat kesempurnaan pelayanan kesehatan dalam menimbulkan rasa puas pada diri setiap pasien. Makin sempurna kepuasan tersebut, makin baik pula mutu pelayanan kesehatan. Kepuasan pelanggan yang rendah akan berdampak terhadap jumlah kunjungan pasien yang akan mempengaruhi profitabilitas fasilitas kesehatan (Azwar, 1996).

Terhitung 1 Januari 2014 Pemerintah membentuk suatu Badan Penyelenggaran Jaminan Sosial Kesehatan yang selanjutnya disingkat BPJS Kesehatan. BPJS Kesehatan adalah badan hukum yang dibentuk untuk menyelenggarakan program Jaminan Kesehatan. Di mana telah diatur bahwa setiap peserta berhak memperoleh pelayanan promotif, preventif, kuratif, dan rehabilitatif termasuk pelayanan obat dan bahan medis pakai sesuai dengan kebutuhan medis yang diperlukan (Peraturan Menkes RI, 2013).

Program pemerintah pada tanggal 1 Januari 2019, seluruh rakyat Indonesia sudah mendapatkan Jaminan Kesehatan Nasional dengan cara mendaftar sebagai peserta pengguna layanan BPJS. Sehingga kepuasan peserta BPJS terhadap mutu pelayanan rumah sakit sangat perlu dipantau. Karena apabila pasien peserta BPJS ternyata tidak mendapatkan kepuasan, maka bukan tidak mungkin rakyat yang belum mendaftar sebagai peserta layanan BPJS tidak akan mau mendaftarkan dirinya. Sehingga program pemerintah pun akan sulit untuk terwujud.

Dalam hal ini meninjau dari tujuan Pemerintah dari program BPJS Kesehatan di atas untuk meningkatkan pelayanan rumah sakit yang maksimal dan dapat mewujudkan terdaftarnya seluruh rakyat Indonesia dalam program 
BPJS, sehingga semestinya kepuasan pasien peserta BPJS terutama terdapat mutu pelayanan kesehatan harus dapat terpenuhi dengan baik.

Namun, banyak keluhan di masyarakat mengenai pelayanan rumah sakit bagi pasien yang menggunakan Jamkesmas, yang sekarang kita kenal sebagai program BPJS. Hasil penelitian Rizki Ari Sandi pada tahun 2011 tentang Hubungan Mutu Pelayanan Kesehatan Dengan Kepuasan Pasien Jamkesmas di Ruang Rawat Inap RSUD dr. Rasidin Kota Padang, didapatkan $82,7 \%$ responden menyatakan tingkat kehandalan petugas tidak baik, $80,2 \%$ responden menyatakan jaminan petugas tidak baik, 79\% responden menyatakan empati petugas tidak baik, 85,2\% reponden menyatakan bukti fisik tidak baik. Hal ini menunjukkan bahwa sebagian besar pasien menyatakan tidak puas terhadap pelayanan yang diberikan petugas kepada pasien Jamkesmas (Sandi, 2011).

\section{METODE}

Penelitian ini mengambil sampel di poliklinik penyakit dalam RS dr. H. Abdul Moeloek Provinsi Lampung, karena RS dr. H. Abdul Moeloek merupakan rumah sakit pendidikan dengan tipe $B$ dan merupakan rumah sakit rujukan tahap akhir di Provinsi Lampung. poliklinik penyakit dalam berdasarkan data yang peneliti dapat dari bagian Rekam Medis RS dr.H. Abdul Moeloek Provinsi Lampung merupakan poliklinik yang paling banyak dikunjungi selama periode 2013. Di mana terdapat 18 poliklinik dan jumlah pengunjung poliklinik penyakit dalam adalah 20.174 pasien. Jenis penelitian ini adalah observasi analitik dengan pendekatan crosssectional. Penarikan sampel menggunakan accidental sampling dengan jumlah sampel 256 orang. Analisis data yang dilakukan adalah univariat dan bivariat dengan uji Chi-square.

\section{HASIL}

Selama waktu penelitian dari bulan Februari sampai Maret 2015 dengan pengumpulan data primer melalui pembagian kuesioner bersifat angket kepada semua peserta BPJS yang berkunjung dan peneliti ditemui di Poliklinik Penyakit Dalam RS dr. H. Abdul Moeloek Provinsi Lampung yang bersedia untuk menjadi responden. Dari satu bulan waktu penelitian didapatkan 256 pasien BPJS yang memenuhi kriteria inklusi dan bersedia menjadi responden penelitian.

Hasil Analisis Univariat. Analisis dilakukan tiap variabel dari hasil penelitian, baik variabel dependent maupun variabel independent. Hasil dari tiap variabel ini ditampilkan dalam bentuk tabel distribusi frekuensi berikut ini.

\section{Jenis Kelamin}

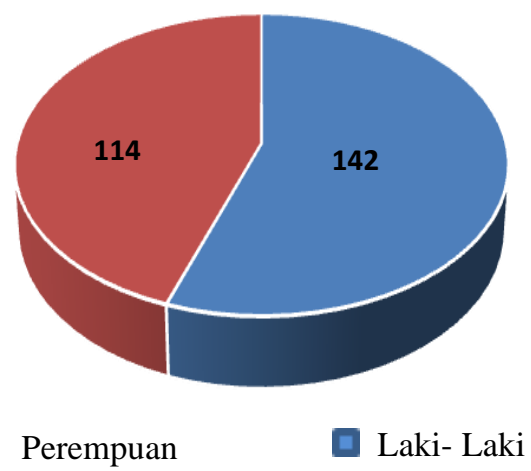

\section{Gambar 1. Distribusi Frekusensi Karakteristik Responden Berdasarkan Jenis Kelamin.}

Berdasarkan Gambar 1 di atas menunjukkan distribusi jenis kelamin responden pasien BPJS Poliklinik penyakit dalam RS dr. H. Abdul Moeloek Provinsi Lampung yang terdiri dari 142 responden (55,5\%) berjenis kelamin perempuan dan 114 responden $(44,5 \%)$ berjenis kelamin laki-laki. 


\section{Usia Responden}

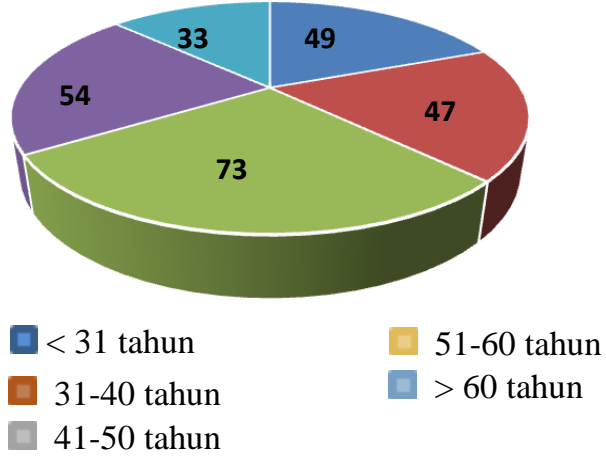

Gambar 2. Distribusi Frekuensi Karakteristik Responden Berdasarkan Usia.

Berdasarkan gambar 2 di atas menunjukkan distribusi frekuensi usia responden pasien BPJS Poliklinik penyakit dalam RS dr. $H$. Abdul Moeloek Provinsi Lampung yang paling banyak jumlahnya adalah usia 41 sampai 50 tahun berjumlah 73 responden $(28,5 \%)$ dan paling sedikit jumlahnya adalah usia di atas 60 tahun berjumlah 33 responden $(12,9 \%)$.

\section{Pendidikan}

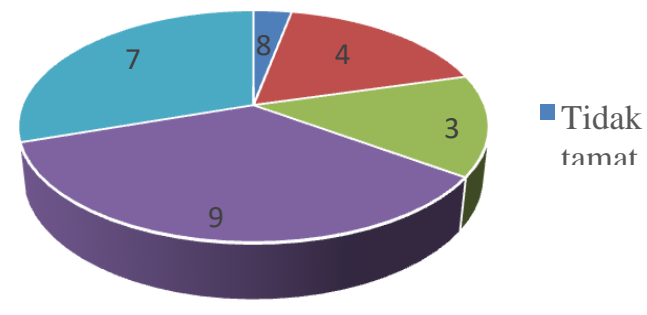

Gambar 3. Distribusi Frekuensi Karakteristik Responden Berdasarkan Pendidikan.

Berdasarkan gambar 3 di atas menunjukkan distribusi frekuensi pendidikan responden pasien BPJS Poliklinik penyakit dalam RSUD dr. $\mathrm{H}$. Abdul Moeloek Provinsi Lampung yang paling banyak jumlahnya adalah responden tamat SLTA berjumlah 90 responden $(35,2 \%)$ dan yang paling sedikit jumlahnya adalah responden tidak tamat SD berjumlah 8 responden $(3,1 \%)$.
Tabel 1. Distribusi frekuensi berdasarkan aspek reliability

\begin{tabular}{ccc}
\hline Reliability & Frekuensi & Persentase \\
\hline Kurang baik & 66 & 25,8 \\
\hline Baik & 190 & 74,2 \\
\hline Total & $\mathbf{2 5 6}$ & $\mathbf{1 0 0 , 0}$ \\
\hline
\end{tabular}

Berdasarkan tabel 1 di atas menunjukkan distribusi frekuensi berdasarkan penilaian dari aspek reliability, dari 256 responden yang diteliti terdiri dari Baik 190 responden $(74,2 \%)$ dan kurang baik 66 responden $(25,8 \%)$.

\section{Tabel 2. Distribusi frekuensi berdasarkan aspek responsiveness}

\begin{tabular}{ccc}
\hline $\begin{array}{c}\text { Responsive- } \\
\text { ness }\end{array}$ & Frekuensi Persentase \\
\hline Kurang baik & 107 & 41,8 \\
\hline Baik & 149 & 58,2 \\
\hline Total & $\mathbf{2 5 6}$ & $\mathbf{1 0 0 , 0}$ \\
\hline
\end{tabular}

Berdasarkan tabel 2 di atas menunjukkan distribusi frekuensi berdasarkan penilaian dari aspek responsiveness, dari 256 responden yang diteliti terdiri dari Baik 149 responden(58,2\%) dan Kurang baik 107 responden $(41,8 \%)$.

\section{Tabel 3. Distribusi frekuensi berdasarkan aspek Assurance}

\begin{tabular}{ccc}
\hline Assurance & Frekuensi & Persentase \\
\hline Kurang baik & 72 & 28,1 \\
\hline Baik & 184 & 71,9 \\
\hline Total & $\mathbf{2 5 6}$ & $\mathbf{1 0 0 , 0}$ \\
\hline
\end{tabular}

Berdasarkan tabel 3 di atas menunjukkan distribusi frekuensi berdasarkan penilaian dari aspek assurance, dari 256 responden yang diteliti terdiri dari Baik 184 responden $(71,9 \%)$ dan kurang baik 72 responden $(28,1 \%)$. 
Tabel 5. Distribusi frekuensi berdasarkan aspek Empathy

Empathy Frekuensi Persentase

\begin{tabular}{ccc}
\hline Kurang baik & 86 & 33,6 \\
\hline Baik & 170 & 66,4 \\
\hline Total & $\mathbf{2 5 6}$ & $\mathbf{1 0 0 , 0}$ \\
\hline
\end{tabular}

Berdasarkan tabel 5 di atas menunjukkan distribusi frekuensi berdasarkan penilaian dari aspek diteliti terdiri dari Baik 170 responden $(66,4 \%)$ dan kurang baik 86 responden $(33,6 \%)$.

empathy, dari 256 responden yang

Tabel 6. Distribusi frekuensi berdasarkan aspek kepuasan

Kepuasan Frekuensi Persentase

\begin{tabular}{ccc}
\hline Kurang puas & 80 & 31,2 \\
\hline Puas & 176 & 68,8 \\
\hline Total & $\mathbf{2 5 6}$ & $\mathbf{1 0 0 , 0}$ \\
\hline
\end{tabular}

Berdasarkan tabel 6 di atas menunjukkan distribusi frekuensi berdasarkan penilaian dari aspek kepuasan, dari 256 responden yang diteliti terdiri dari Puas 176 responden $(68,8 \%)$ dan Kurang puas 80 responden $(31,2 \%)$.

\section{Hasil Analisis Bivariat}

Analisis ini digunakan untuk melihat hubungan antara mutu pelayanan Poliklinik penyakit dalam RSUD dr. H. Abdul Moeloek Provinsi Lampung dengan kepuasan pasien.

Hubungan antara tengible, reliability, responsiveness, assurance, empathy dengan kepuasan pasien yang dihitung satu per satu. Uji statistik yang digunakan pada analisis bivariat ini adalah Chi Square dengan derajat kepercayaan 95\% (a $=95 \%$ ). Berdasarkan hasil uji statistik akan diperoleh nilai probabilitas ( $p$-value) $\leq 0,05$ (pada $\mathrm{CI} ; 95 \%)$ maka $\mathrm{Ho}$ ditolak dan $\mathrm{Ha}$ diterima yang berarti ada hubungan yang bermakna dan jika probabilitas ( $p$-value $)>0,05$ maka Ho diterima dan Ha ditolak yang berarti tidak ada hubungan yang bermakna.

Tabel 8. Hubungan antara Tangible, Reliability, Responsiveness, Assurance, Empathy dan Kepuasan

\begin{tabular}{|c|c|c|c|c|c|c|c|c|c|}
\hline \multirow{3}{*}{ No. } & \multirow{3}{*}{ Kategori } & \multicolumn{3}{|c|}{ Kepuasan } & \multirow{2}{*}{\multicolumn{3}{|c|}{ Jumlah }} & \multirow{3}{*}{$\begin{array}{l}\text { OR/CI } \\
(95 \%)\end{array}$} & \multirow{3}{*}{ p-value } \\
\hline & & \multicolumn{2}{|c|}{ Kurang Puas } & \multirow{2}{*}{$\frac{\text { Puas }}{\mathbf{N}}$} & & & & & \\
\hline & & $\mathbf{N}$ & $\%$ & & $\%$ & $\mathbf{N}$ & $\%$ & & \\
\hline \multicolumn{10}{|c|}{1 Tangible } \\
\hline & -Kurang baik & 27 & 56,2 & 21 & 43,8 & 48 & 100 & $3,76 /$ & \multirow{3}{*}{0,000} \\
\hline & -Baik & 53 & 25,5 & 155 & 74,5 & 208 & 100 & 1,9 & \\
\hline & Jumlah & 80 & - & 176 & - & 256 & - & 7,202 & \\
\hline \multirow[t]{5}{*}{2} & Reliability & & & & & & & \multirow{4}{*}{$\begin{array}{c}2,549 / \\
1,423- \\
4,563\end{array}$} & \multirow{4}{*}{0,002} \\
\hline & - Kurang baik & 31 & 47,0 & 35 & 53,0 & 66 & 100 & & \\
\hline & - Baik & 49 & 25,8 & 141 & 74,2 & 190 & 100 & & \\
\hline & Jumlah & 80 & - & 176 & - & 256 & - & & \\
\hline & Responsiveness & & & & & & & \multirow{4}{*}{$\begin{array}{c}3,216 / \\
1,858- \\
5,567\end{array}$} & \multirow{4}{*}{0,000} \\
\hline \multirow{3}{*}{3} & - Kurang baik & 49 & 45,8 & 58 & 54,2 & 107 & 100 & & \\
\hline & - Baik & 31 & 20,8 & 118 & 79,2 & 149 & 100 & & \\
\hline & Jumlah & 80 & - & 176 & - & 256 & - & & \\
\hline \multirow[t]{3}{*}{4} & Assurance & & & & & & & & \\
\hline & - Kurang baik & 42 & 58,3 & 30 & 41,7 & 72 & 100 & 5,379/ & \multirow[b]{2}{*}{0,000} \\
\hline & - Baik & 38 & 20,7 & 146 & 79,3 & 184 & 100 & 2,985- & \\
\hline
\end{tabular}




\begin{tabular}{lcccccccc} 
Jumlah & 80 & - & 176 & - & 256 & - & 9,694 & \\
\hline 5 Empathy & & & & & & & & \\
- Kurang baik & 52 & 60,5 & 34 & 39,5 & 86 & 100 & $7,756 /$ & \\
- Baik & 28 & 16,5 & 142 & 83,5 & 170 & 100 & $4,289-$ & 0,000 \\
Jumlah & 80 & - & 176 & - & 256 & - & 14,028 & \\
\hline
\end{tabular}

Berdasarkan tabel 8 dapat disimpulkan bahwa dari semua variabel independent yaitu tengible, reliability, responsiveness, assurance, empathy memiliki hubungan dengan variabel dependent yaitu kepuasan peserta BPJS di poliklinik penyakit dalam RS dr. H. Abdul Moeloek Provinsi Lampung 2015 karena hasil uji chi-square menunjukkan seluruh nilai $p$-value berada di bawah 0,05. Dari 256 responden ada sejumlah 176 responden $(68,8 \%)$ yang merasa puas dan 80 responden $(31,2 \%)$ merasa kurang puas. Kemudian lebih lengkapnya diinterpretasikan oleh peneliti sebagai berikut:

\section{PEMBAHASAN}

\section{A. Hubungan antara Tangible dan Kepuasan Peserta BPJS}

Berdasarkan tabel 4.7

diketahui bahwa dari 48 responden yang merasa tangible tidak baik terdapat 27 responden $(56,2 \%)$ yang kurang puas dan 21 responden $(43,8 \%)$ yang puas. Sedangkan dari 186 responden yang merasa tangible baik terdapat 53 responden $(25,5 \%)$ yang kurang puas dan 155 responden $(74,5 \%)$ yang puas.

Hasil uji statistik Chi-Square didapatkan nilai $p$-value $=0,000(p$ value $<a=0,05$ ) yang berarti ada hubungan antara tangible dan kepuasan pasien BPJS di poliklinik penyakit dalam RS dr. H. Abdul Moeloek Provinsi Lampung 2015. Kemudian didapatkan nilai $\mathrm{OR}=3,76$ yang berarti bahwa peserta BPJS yang merasa mutu pelayanan tangible kurang baik mempunyai risiko sebanyak 3,76 kali untuk kurang puas dibandingkan peserta BPJS yang merasa mutu pelayanan tangible baik. Di mana nilai OR tersebut berada di antara Confident Interval 1,963-7,202 dengan selisih OR dan Upper '3,442 dan selisih OR dan Lower 1,797. Hal ini meunjukkan bahwa rentan tingkat kepercayaan pada aspek tangible tinggi, karena terdapatnya selisih yang tidak terlalu signifikan antara upper dan lower terhadap OR.

Hasil ini juga sesuai dengan teori yang ada, bahwa menurut Kotler pada tahun 2000 kualitas jasa harus dimulai dari kebutuhan pelanggan dan berakhir dengan kepuasan pelanggan serta serta persepsi positif terhadap kualitas jasa (Tjiptono dan Chandra, 2011). Di mana salah satu dimensi kualitas jasa adalah tangible.

Hasil penelitian ini sejalan dengan hasil penelitian Siswati (2015) di RSUD Kota Makassar yang mengatakan bahwa ada hubungan antara Tangible $=0,000(p<0,05)$ dengan kepuasan pasien BPJS di unit rawat inap RSUD Kota Makassar (Ningrum, 2014).

Dalam penelitian ini, adanya hubungan antara tengible dan kepuasan pasien, karena fasilitas yang ada di poliklinik penyakit dalam sudah memadai dan sudah cukup bagus, hanya dalam beberapa aspek yang dikeluhkan oleh pasien, seperti kerapihan meja perawat. Namun aspek tersebut sangat mempengaruhi pasien, terlihat dari banyaknya pasien yang merasa aspek tangible tidak baik, sebesar $18,8 \%$ dari total responden di poliklinik.

Seperti yang telah dijelaskan sebelumnya, bahwa pelayanan yang baik akan mempengaruhi kepuasan. Itu berarti fasilitas yang baik akan mempengaruhi kepuasan. Berdasarkan pandangan peneliti di tempat penelitian, dan dari data yang telah didapatkan, bisa disimpulkan bahwa memang ada hubungan antara tangible dengan kepuasan peserta BPJS poliklinik penyakit 
dalam RS dr. H. Abdul Moeloek Provinsi Lampung 2015.

Kemudian walaupun ada 190 responden yang menilai pelayanan tangible baik tetapi masih ada 49 responden di antaranya yang merasa kurang puas dan sebaliknya walaupun ada 48 responden yang menilai pelayanan tangible kurang baik tetapi masih ada 21 responden di antaranya yang merasa puas, hal ini menurut pandangan peneliti dipengaruhi oleh berbagai karakteristik responden yang diteliti sehingga memiliki persepsi yang berbeda-beda.

\section{B. Hubungan antara Reliability dan Kepuasan Peserta BPJS} Berdasarkan tabel 4.7 diketahui bahwa dari 66 responden yang merasa reliability tidak baik terdapat 31 responden $(47,0 \%)$ yang kurang puas dan 35 responden $(53,0 \%)$ yang puas. Sedangkan dari 190 responden yang merasa reliability baik terdapat 49 responden $(25,8 \%)$ yang kurang puas dan 141 responden $(74,2 \%)$ yang puas. Hasil uji statistik Chi-Square didapatkan nilai $p$-value $=$ 0,002 ( $p$-value $<a=0,05$ ) yang berarti ada hubungan antara reliability dan kepuasan pasien BPJS di poliklinik penyakit dalam RS dr. $H$. Abdul Moeloek Provinsi Lampung 2015.

Kemudian didapatkan nilai OR $=2,549$ yang berarti bahwa peserta BPJS yang merasa mutu pelayanan reliability kurang baik mempunyai risiko sebanyak 2,549 kali untuk kurang puas dibandingkan peserta BPJS yang merasa mutu pelayanan reliability baik. Di mana nilai OR tersebut berada di antara Confident Interval 1,423-4,563 dengan selisih OR dan Upper '2,014 dan selisih OR dan Lower 1,126. Hal ini meunjukkan bahwa rentan tingkat kepercayaan pada aspek reliability tinggi, karena terdapatnya selisih yang tidak terlalu signifikan antara upper dan lower terhadap OR.

Hasil ini juga sesuai dengan teori yang ada, bahwa menurut Kotler pada tahun 2000 kualitas jasa harus dimulai dari kebutuhan pelanggan dan berakhir dengan kepuasan pelanggan serta serta persepsi positif terhadap kualitas jasa (Tjiptono dan Chandra, 2011). Di mana salah satu dimensi kualitas jasa adalah reliability.

Hasil penelitian ini sejalan dengan hasil penelitian Siswati (2015) di RSUD Kota Makassar yang mengatakan bahwa ada hubungan antara reliability $=0,001(p<0,05)$ dengan kepuasan pasien BPJS di unit rawat inap RSUD Kota Makassar (Ningrum, 2014).

Dalam penelitian ini, adanya hubungan antara reliability dan kepuasan pasien, karena fasilitas yang ada di poliklinik penyakit dalam sudah memadai dan sudah cukup bagus, hanya dalam beberapa aspek yang dikeluhkan oleh pasien, seperti ketepatan waktu dokter dan waktu tunggu di poliklinik. Namun aspek tersebut sangat mempengaruhi pasien, terlihat dari banyaknya pasien yang merasa aspek reliability tidak baik, sebesar $25,8 \%$ dari total responden di poliklinik.

Seperti yang telah dijelaskan sebelumnya, bahwa pelayanan yang baik akan mempengaruhi kepuasan. Itu berarti fasilitas yang baik akan mempengaruhi kepuasan.

Berdasarkan

pandangan peneliti di tempat penelitian, dan dari data yang telah didapatkan, bisa disimpulkan bahwa memang ada hubungan antara reliability dengan kepuasan peserta BPJS poliklinik penyakit dalam RS dr. H. Abdul Moeloek Provinsi Lampung 2015.

Kemudian walaupun ada 190 responden yang menilai pelayanan reliability baik tetapi masih ada 49 responden di antaranya yang merasa kurang puas dan sebaliknya walaupun ada 66 responden yang menilai pelayanan reliability kurang baik tetapi masih ada 35 responden di antaranya yang merasa puas, hal ini menurut pandangan peneliti dipengaruhi oleh berbagai karakteristik responden yang diteliti sehingga memiliki persepsi yang berbeda-beda. 


\section{Hubungan antara \\ Responsiveness dan Kepuasan Peserta BPJS}

Berdasarkan tabel 8 diketahui bahwa dari 107 responden yang merasa responsiveness kurang baik terdapat 49 responden $(45,8 \%)$ yang kurang puas dan 58 responden $(54,2 \%)$ yang puas. Sedangkan dari 149 responden yang merasa responsiveness baik terdapat 31 responden $(20,8 \%)$ yang kurang puas dan 118 responden $(79,2 \%)$ yang puas.

Hasil uji statistik Chi-Square didapatkan nilai $p$-value $=0,000(p$ value $<a=0,05$ ) yang berarti ada hubungan antara responsiveness dan kepuasan peserta BPJS di poliklinik penyakit dalam RS dr. H. Abdul Moeloek Provinsi Lampung 2015. Kemudian didapatkan nilai OR = 3,216 yang berarti bahwa peserta BPJS yang merasa mutu pelayanan responsiveness kurang baik mempunyai risiko sebanyak 3,216 kali untuk tidak puas dibandingkan peserta BPJS yang merasa mutu pelayanan responsiveness. Di mana nilai OR tersebut berada di antara Confident Interval 1,858-5,567 dengan selisih OR dan Upper '2,351 dan selisih OR dan Lower 1,358. Hal ini meunjukkan bahwa rentan tingkat kepercayaan pada aspek responsiveness tinggi, karena terdapatnya selisih yang tidak terlalu signifikan antara upper dan lower terhadap OR.

Hasil ini juga sesuai dengan teori yang ada, bahwa menurut Kotler pada tahun 2000 kualitas jasa harus dimulai dari kebutuhan pelanggan dan berakhir dengan kepuasan pelanggan serta serta persepsi positif terhadap kualitas jasa (Tjiptono dan Chandra, 2011). Di mana salah satu dimensi kualitas jasa adalah responsiveness.

Hasil penelitian ini sejalan dengan hasil penelitian Siswati (2015) di RSUD Kota Makassar yang mengatakan bahwa ada hubungan antara responsiveness $=0,001$ ( $p<$ 0,05 ) dengan kepuasan pasien BPJS di unit rawat inap RSUD Kota Makassar (Ningrum, 2014).

Dalam penelitian ini, adanya hubungan antara responsiveness dan kepuasan pasien, karena fasilitas yang ada di poliklinik penyakit dalam sudah memadai dan sudah cukup bagus, hanya dalam beberapa aspek yang dikeluhkan oleh pasien, seperti perawat tidak memberikan nomor antrean. Namun aspek tersebut sangat mempengaruhi pasien, terlihat dari banyaknya pasien yang merasa aspek responsiveness tidak baik, sebesar $41,8 \%$ dari total responden di poliklinik.

Seperti yang telah dijelaskan sebelumnya, bahwa pelayanan yang baik akan mempengaruhi kepuasan. Itu berarti fasilitas yang baik akan mempengaruhi kepuasan. Berdasarkan pandangan peneliti di tempat penelitian, dan dari data yang telah didapatkan, bisa disimpulkan bahwa memang ada hubungan antara responsiveness dengan kepuasan pasien BPJS poliklinik penyakit dalam RS dr. H. Abdul Moeloek Provinsi Lampung 2015. Kemudian walaupun ada 149 responden yang menilai pelayanan responsiveness baik tetapi masih ada 31 responden di antaranya yang merasa kurang puas dan sebaliknya walaupun ada 107 responden yang menilai pelayanan responsiveness kurang baik tetapi masih ada 58 responden di antaranya yang merasa puas, hal ini menurut pandangan peneliti dipengaruhi oleh berbagai karakteristik responden yang diteliti sehingga memiliki persepsi yang berbeda-beda.

\section{Hubungan antara Assurance dan Kepuasan Peserta BPJS}

Berdasarkan tabel 8 diketahui bahwa dari 72 responden yang merasa assurance kurang baik terdapat 42 responden $(58,3 \%)$ yang kurang puas dan 30 responden $(41,7 \%)$ yang puas. Sedangkan dari 184 responden yang merasa assurance baik terdapat 38 responden $(20,7 \%)$ yang kurang puas dan 146 
responden $(79,3 \%)$ yang puas.

Hasil uji statistik Chi-Square didapatkan nilai $p$-value $=0,000$ ( $p$ value $<a=0,05$ ) yang berarti ada hubungan antara assurance dan kepuasan peserta BPJS di poliklinik penyakit dalam RSUD dr. H. Abdul Moeloek Provinsi Lampung 2015. Kemudian didapatkan nilai OR = 5,379 yang berarti bahwa peserta BPJS yang merasa mutu pelayanan assurance kurang baik mempunyai risiko sebanyak 5,379 kali untuk tidak puas dibandingkan peserta BPJS yang merasa mutu pelayanan assurance baik. Di mana nilai OR tersebut berada di antara Confident Interval 2,985-9,694 dengan selisih OR dan Upper 4,315 dan selisih OR dan Lower 2,394. Hal ini menunjukkan bahwa rentan tingkat kepercayaan pada aspek assurance rendah, karena terdapatnya selisih yang cukup signifikan antara upper dan lower terhadap OR.

Hasil ini juga sesuai dengan teori yang ada, bahwa menurut Kotler pada tahun 2000 kualitas jasa harus dimulai dari kebutuhan pelanggan dan berakhir dengan kepuasan pelanggan serta serta persepsi positif terhadap kualitas jasa (Tjiptono dan Chandra, 2011) Di mana salah satu dimensi kualitas jasa adalah assurance.

Hasil penelitian ini tidak sejalan dengan hasil penelitian Siswati (2015) di RSUD Kota Makassar yang mengatakan bahwa ada tidak ada hubungan antara assurance $=0,491$ $(p<0,05)$ dengan kepuasan pasien BPJS di unit rawat inap RSUD Kota Makassar (Ningrum, 2014).

Perbedaan ini menurut pendapat peneliti bisa disebabkan karena perbedaan karakteristik sampel penelitian yang diteliti. Kemudian walaupun ada 184 responden yang menilai pelayanan assurance baik tetapi masih ada 38 responden di antaranya yang merasa kurang puas dan sebaliknya walaupun ada 72 responden yang menilai pelayanan assurance kurang baik tetapi masih ada 30 responden di antaranya yang merasa puas, lalu rendahnya rentang tingkat kepercayaan pada aspek assurance juga dipengaruhi oleh banyaknya sampel penelitian yang memilki karakteristik berbeda-beda.

\section{E. Hubungan antara Empathy dan Kepuasan Peserta BPJS}

Berdasarkan tabel 8 diketahui bahwa dari 86 responden yang merasa empathy kurang baik terdapat 52 responden $(60,5 \%)$ yang kurang puas dan 34 responden $(39,5 \%)$ yang puas. Sedangkan dari 170 responden yang merasa empathy baik terdapat 28 responden $(16,5 \%)$ yang kurang puas dan 142 responden $(83,5 \%)$ yang puas.

Hasil uji statistik Chi-Square didapatkan nilai $p$-value $=0,000(p$ value $<a=0,05$ ) yang berarti ada hubungan antara empathy dan kepuasan peserta BPJS di poliklinik penyakit dalam RSUD dr. H. Abdul Moeloek Provinsi Lampung 2015. Kemudian didapatkan nilai OR = 7,756 yang berarti bahwa peserta BPJS yang merasa mutu pelayanan empathy kurang baik mempunyai risiko sebanyak 7,756 kali untuk kurang puas dibandingkan peserta BPJS yang merasa mutu pelayanan empathy baik. Di mana nilai OR tersebut berada di antara Confident Interval 4,289-14,028 dengan selisih OR dan Upper '6,272 dan selisih OR dan Lower 3,467. Hal ini meunjukkan bahwa rentan tingkat kepercayaan pada aspek empathy rendah, karena terdapatnya selisih yang cukup signifikan antara upper dan lower terhadap OR. Hasil ini juga sesuai dengan teori yang ada, bahwa menurut Kotler pada tahun 2000 kualitas jasa harus dimulai dari kebutuhan pelanggan dan berakhir dengan kepuasan pelanggan serta serta persepsi positif terhadap kualitas jasa (Tjiptono dan Chandra, 2011). Di mana salah satu dimensi kualitas jasa adalah empathy. Dari hasil penelitian, setelah dilakukan uji statistik Chi- Square didapatkan adanya hubungan antara empathy dan kepuasan pasien BPJS di poliklinik 
penyakit dalam RS dr. $\mathrm{H}$. Abdul Moeloek Provinsi Lampung 2015, hasil ini dapat dilihat dari nilai $p$-value $=$ $0,000$ ( $p$ - value $<a=0,05)$. Kemudian didapatkan bahwa nilai OR = 7,756 yang berarti bahwa peserta BPJS yang merasa mutu pelayanan empathy kurang baik mempunyai risiko sebanyak 7,756 kali untuk kurang puas dibandingkan peserta BPJS yang merasa mutu pelayanan empathy baik.

Hasil penelitian ini sejalan dengan hasil penelitian Siswati (2015) di RSUD Kota Makassar yang mengatakan bahwa ada hubungan antara empathy $=0,001(p<0,05)$ dengan kepuasan pasien BPJS di unit rawat inap RSUD Kota Makassar (UU RI No. 44, 2009).

Dalam penelitian ini, adanya hubungan antara empathy dan kepuasan pasien, karena fasilitas yang ada di poliklinik penyakit dalam sudah memadai dan sudah cukup bagus, hanya dalam beberapa aspek yang dikeluhkan oleh pasien, seperti keramahan perawat. Namun aspek tersebut sangat mempengaruhi pasien, terlihat dari banyaknya pasien yang merasa aspek empathy tidak baik, sebesar $33,6 \%$ dari total responden di poliklinik.

Seperti yang telah dijelaskan sebelumnya, bahwa pelayanan yang baik akan mempengaruhi kepuasan. Itu berarti fasilitas yang baik akan mempengaruhi kepuasan. Berdasarkan pandangan peneliti di tempat penelitian, dan dari data yang telah didapatkan, bisa disimpulkan bahwa memang ada hubungan antara empathy dengan kepuasan peserta BPJS poliklinik penyakit dalam RS dr. $\mathrm{H}$. Abdul Moeloek Provinsi Lampung 2015. Kemudian walaupun ada 170 responden yang menilai pelayanan empathy baik tetapi masih ada 28 responden di antaranya yang merasa kurang puas dan sebaliknya walaupun ada 86 responden yang menilai pelayanan empathy kurang baik tetapi masih ada 34 responden di antaranya yang merasa puas, lalu rendahnya rentang tingkat kepercayaan pada aspek empathy juga dipengaruhi oleh banyaknya sampel penelitian yang memilki karakteristik berbeda-beda.

\section{F. Kepuasan Peserta BPJS terhadap Mutu Pelayanan Kesehatan di Poliklinik Penyakit Dalam RSUD dr. $H$. Abdul Moeloek Provinsi Lampung 2015}

Hasil dari penelitian ini yaitu didapatkan dari 256 responden yang diteliti terdiri dari Puas 176 responden $(68,8 \%)$ dan 80 responden $(31,2 \%)$ dan Kurang puas. Hal ini menunjukkan bahwa pasien yang puas lebih banyak daripada yang kurang puas.

Teori yang ada menyatakan bahwa pelayanan kesehatan yang bermutu yaitu pelayanan kesehatan yang dapat memuaskan pengguna jasa layanan kesehatan. ${ }^{6}$ Berarti dapat disimpulkan bahwa mutu pelayanan kesehatan di poliklinik penyakit dalam RS dr. H. Abdul Moeloek Provinsi Lampung berdasarkan tangible, reliability, responsiveness, assurance dan empathy sudah cukup baik.

Seperti yang dijelaskan sebelumnya bahwa kepuasan adalah tingkat keadaan yang dirasakan seseorang yang merupakan hasil dari membandingkan penampilan atau outcome produk yang dirasakan dalam hubungannya dengan harapan seseorang (Wiyono, 1999). Berarti dapat disimpulkan bahwa pelayanan yang diharapkan dari tangible, reliability, responsiveness, assurance dan empathy di poliklinik penyakit dalam RSUD dr. H Abdul Moeloek Provinsi Lampung sudah cukup banyak yang sesuai dengan pelayanan tangible, reliability, responsiveness, assurance dan empathy yang diberikan di poliklinik penyakit dalam RS dr. H. Abdul Moeloek Provinsi Lampung. Hasil dari penelitian ini sejalan dengan penelitian yang berjudul Hubungan Mutu Pelayanan Kesehatan BPJS terhadap Kepuasan Pasien di 
Poliklinik THT Rumkital dr. Ramelan Surabaya yang mengatakan bahwa kepuasan pasien terhadap mutu pelayanan kesehatan lebih tinggi daripada pasien yang tidak puas.

Dari hasil yang didapatkan, terlihat bahwa terdapat selisih yang cukup besar antara pasien yang merasa puas dan pasien yang merasa kurang puas. Menurut pandangan peneliti, dari kelima aspek yang diteliti, aspek yang lebih mempengaruhi besarnya angka tidak puasnya pasien yaitu di dalam aspek responsiveness. Hal ini dapat dilihat dari pasien yang merasa pelayanan responsiveness kurang baik lebih banyak daripada aspek yang lainnya. Dan juga dari apa yang dilihat peneliti di lapangan, pelayanan dari aspek responsiveness memang kurang baik daripada aspek yang lain, tetapi karena keempat aspek yang lain sudah cukup baik sehingga terdapat selisih yang cukup besar antara pasien yang merasa puas dan pasien yang merasa kurang puas.

\section{KESIMPULAN}

Berdasarkan hasil penelitian dan pembahasan, maka terdapat beberapa kesimpulan sebagai berikut:

1. Angka presentase peserta BPJS yang puas $68,8 \%$ dan peserta BPJS yang kurang puas yaitu $31,2 \%$ di poliklinik penyakit dalam RS dr.H.Abdul Moeloek Provinsi Lampung.

2. Ada hubungan antara tengible dan kepuasan pasien BPJS di poliklinik penyakit dalam RS dr. H. Abdul Moeloek Provinsi Lampung 2015.

3. Ada hubungan antara reliability dan kepuasan pasien BPJS di poliklinik penyakit dalam RS dr. H. Abdul Moeloek Provinsi Lampung 2015.

4. Ada hubungan antara responsiveness dan kepuasan pasien BPJS di poliklinik penyakit dalam RS dr. $\mathrm{H}$. Abdul Moeloek Provinsi Lampung 2015.
5. Ada hubungan antara assurance dan kepuasan pasien BPJS di poliklinik penyakit dalam RS dr. $\mathrm{H}$. Abdul Moeloek Provinsi Lampung 2015.

6. Ada hubungan antara empathy dan kepuasan pasien BPJS di poliklinik penyakit dalam RS dr. H. Abdul Moeloek Provinsi Lampung 2015.

\section{DAFTAR PUSTAKA}

Azwar, A. (1996). Menjaga Mutu Pelayanan Kesehatan. Edisi 2. Jakarta: Pustaka Sinar Harapan. H. 24-30.

(2010). Pengantar Administrasi Kesehatan. Edisi Ketiga. Tangerang: Binarupa Aksara. H. 22-33.

Departemen Kesehatan RI. Data Rumah Sakit Online. Diakses tanggal 15 Februari 2015, dari: www.sirs.buk.depkes.go.id/rso nline

Departemen Kesehatan Republik Indonesia. (2002). Pedoman Peraturan Internal Rumah Sakit. Jakarta: Keputusan Menteri Kesehatan Republik Indonesia No. 772 Tahun 2002. Diakses dari: www.manajemenrumahsakit.n et

Menteri Kesehatan RI. (2013). Peraturan Menteri Kesehatan Republik Indonesia Nomor 71 Tahun 2013. Diakses tanggal 21 November 2014, dari: http://www.depkes.go.id

Ningrum, M., R. (2014). Hubungan Mutu Pelayanan Kesehatan BPJS terhadap Kepuasan Pasien di Poli Klinik THT Rumkital Dr. Ramelan Surabaya. Jurnal. Program Studi Keperawatan Stikes Hangtuah.

Sandi, R.A. (2011). Hubungan Mutu Pelayanan Kesehatan Dengan Tingkat Kepuasan Pasien Jamkesmas Di Ruang Rawat Inap RSUD dr. Rasidin Kota 
Padang Tahun 2011. [Skripsi]. Program Studi Ilmu Kesehatan Masyarakat Kedokteran Fakultas Universitas Andalas.

Siswati, S. (2015). Hubungan Kualitas Pelayanan Kesehatan dengan Kepuasan Pasien BPJS di Unit Rawat Inap RSUD Kota Makassar. 2015. [Skripsi]. Program Studi Ilmu Kesehatan Masyarakat Universitas Hasanudin.

Tjiptono, F dan Chandra, G. (2011). Service, Quality \& Satisfaction.
Edisi ketiga. Yogyakarta: ANDI. H. 196-198, 292.

Undang-Undang Republik Indonesia. (2009). UU RI No.44 Tahun 2009 Rumah Sakit. Jakarta: Lembaran Negara Republik Indonesia Tahun 2009 Nomor 153. Diakses tanggal 15 Februari 2015, dari: www.gizikia.depkes.go.id Wiyono, D. (1999). Manajemen Mutu Kesehatan. Buku I. Surabaya: Airlangga University Press. $\mathrm{H}$. 13-37. 